\title{
Value-Based Training of the Would-be Specialists
}

\author{
Nelly Savelyeva \\ Dept of Foreign Languages and Educational Technologies \\ Ural Federal University named after the first President of \\ Russia B.N. Eltsyn \\ Ekaterinburg, Russia \\ nellik1983@mail.ru \\ Elena Gnatyshina \\ Dept of Training Teachers of Vocational Training and \\ Subject-Specific Methods \\ South-Ural State Humanitarian Pedagogical University \\ Chelyabinsk, Russia \\ mopr9@mail.ru

\section{Natalya Uvarina} \\ Dept of Training Teachers of Vocational Training and \\ Subject-Specific Methods \\ South-Ural State Humanitarian Pedagogical University \\ Chelyabinsk, Russia nuvarina@yandex.ru
}

\begin{abstract}
The focus on the internationalization of modern higher education in the context of globalization processes inevitably leads to the increased interaction of languages and cultures, which makes it necessary for students to develop the ability to effectively realize themselves in professional contexts at the level of intercultural interaction. The article considers the professional axiological paradigm of pedagogy as a strategic guideline for the development of higher education in different fields.
\end{abstract}

Keywords - professional-axiological competence; professional training; intercultural interaction; would-be specialists.

\section{INTRODUCTION}

Internationalization has been considered to be one of the major trends in the development of higher education in the recent years. However, many would agree that, particularly at institutional level, there is often a gap between the rhetoric and the reality of internationalization. How to promote internationalization strategies and how to cope with various pressing trends and challenges at institutional level are questions which are still begging for appropriate replies, and from these replies, appropriate solutions [1].

Russia's accession to the threshold of the XXI century is accompanied, first of all, by the development of a democratic society, a constitutional state, and a market economy in the country. These national interests are also in tune with the global trends of globalization, integration in all spheres of public life, the transition to an information society, acceleration of economic development, expansion of intercultural interaction. These factors activate mass migration

\author{
Alexey Savchenkov \\ Dept of Training Teachers of Vocational Training and \\ Subject-Specific Methods \\ South-Ural State Humanitarian Pedagogical University \\ Chelyabinsk, Russia \\ alex2107@mail.ru
}

\section{Olga Pavlova}

Dept of Foreign Languages

South-Ural State Humanitarian Pedagogical University

Chelyabinsk Russia

o.yu.pavlova@mail.ru

\author{
Rinat Kusarbaev \\ Dept of Foreign Languages \\ South-Ural State Humanitarian Pedagogical University \\ Chelyabinsk Russia \\ rinkus@inbox.ru
}

of the population, aggravation of interethnic conflicts, the growth of global problems, the spiritual crisis of society.

The powerful system of multicultural and international education, which functioned for many decades in the USSR, is losing its relevance. It is replaced by new values, recognized by the leading teachers of New Russia as the main guidelines of the education process. For example, N. D. Nikandrov sees one of the main goals of the educational process in the formation of a patriot of Russia, aimed at prioritizing the values of the country, while recognizing the values of other countries and cultures [2]. The Pedagogical concept proposed by V. A. Karakovsky [3], the main reference point of the educational process, proclaims world as peace and harmony between people, peoples and States.

Analysis of state documents in the field of science and education since the beginning of 2000 (the RF Government Decree № 751 "On the National Doctrine of Education in Russian Federation" (dated October 4, 2000), the Concept of Modernization of Russian Education for the period till 2020 (dated 29.12.2014 No. 2765), Federal Law "About Education in the Russian Federation" (29.12.2012 No. 273-FL) also testifies to the recognition from the part of the government of the Russian Federation the importance of forming a culture of interpersonal relations, education of tolerance and respect for representatives of other peoples and cultures [4].

In accordance with The Law about education of 29.12.2012, the state policy in the field of education is aimed at the historical continuity of generations, preservation, dissemination and development of national culture, education of respect for the historical and cultural heritage of the peoples of Russia; the education of Russian patriots who respect the 
rights and freedoms of the individual, have high morals and show national and religious tolerance, respect languages, traditions and culture of other peoples. The modern policy of the Russian Federation in the field of education has a humanistic orientation, highlighting the priority of universal values, human life, and health, free development of the individual.

The growing dynamism of international relations and business, the internationalization of business contacts, the need to compete effectively in the international arena necessitates more coordinated interaction, the ability to conduct an effective dialogue with representatives of various cultures. In the modern world, when the environment is becoming more international, multiculturalism is a part of everyday life and requires all participants in the communicative process of mutual respect, acceptance, and understanding.

Today, a person's competitiveness in the labor market largely depends on his ability to master new technologies and adapt to changing working conditions. Modern competencybased higher professional education is designed to meet the requirements of the time. The main result of education should not be a system of knowledge, skills, but key competences declared by the state in the intellectual, socio-political, communication, information, and other fields.

One of the main goals of a modern university is to train specialists for different fields of economics, able to meet the challenges of our time, which involves not only the translation of ready-made knowledge, but also the creation of new knowledge. The modern education system is focused on the formation of intellectual potential of the nation and the holistic development of the individual as the highest societal value. Thus, one of the major trends of the national educational strategy presently is to move to the value paradigm. This model appeals to those education institutions which share with their pupils some common principles, i.e. teach them national and world culture and their values. This attitude calls for the introduction of value orientation in higher pedagogical education, greater attention to the personality of the future specialists, their axiosphere, as well as ideological position and value-based guidelines.

To date, a significant number of approaches and concepts has been developed in pedagogical science that implements the tasks of training a specialist in the conditions of University education. At the same time, it should be noted that the main attention in the existing achievements of pedagogy is paid to external circumstances and parameters of the educational process, and internal, personal reserves of ensuring high performance of the learning process in higher education and intercultural resources to improve the quality of education are not fully disclosed.

The urgency of the problem of professional axiological training of future specialists is determined by the need to:

the formation of the personality of the future specialists, able to navigate socially significant values, to effectively interact with different people in a situation of intercultural dialogue, which is caused by social order and legal support of the modern educational policy of the Russian Federation;

- development of theoretical bases of preparation of future specialists to the investigated phenomenon in the conditions of modern Russian higher school;

- development and approbation of the system and pedagogical conditions providing productive process of preparation of future specialists to intercultural interaction.

\section{RESEARCH METHODS}

The study will be conducted using a set of theoretical and empirical methods.

Theoretical methods: a) analysis of normative documents on education used to justify the relevance of the problem and identify the legal possibilities for its solution; b) historicalpedagogical analysis is used to build a historiography of the research problem; c) theoretical and methodological analysis allows us to formulate the original position of the research; d) conceptual and terminological analysis is aimed at description of the conceptual field problems; d) system analysis provides the basis for holistic treatment of the problem.

Empirical methods: a) research and generalization of effective experience and mass practice of training future specialists; b) ascertaining experiment to assess the level of readiness of future specialists to intercultural interaction; c) forming an experiment on the practical implementation of the system of training future specialists to intercultural interaction and the proposed pedagogical conditions of its effective functioning; d) observation, questioning, testing, ranking, examination, interview; e) mathematical methods of processing and evaluation of information data and verification of hypotheses.

\section{RESULTS AND DISCUSSION}

Education is the main channel for introducing future specialists to the values of culture, education, and profession [5]. In this sense, it becomes clear, since University education is a fundamental scientific and practical basis for the formation of the young generation of real ideas about the real and imaginary values of life and activity, expressing the social, legal and moral norms of society.

Let us consider the selected concepts in more detail in accordance with the above provisions.

"Culture" is a fundamental term of anthropology, sociology, philosophy, ethnology, linguistics, and many other areas of knowledge, which interpret it differently [6]. At the moment there are several hundred different definitions of this term. The variety of concepts of culture determines the desire of researchers to systematize them. One of the most common classifications belongs to A. Kröber and K. Klakhon [7], who identified six types of definitions of culture (descriptive, historical, normative, psychological, structural, and genetic ones). Here are some interpretations of this concept, identified in the framework of certain areas of its study: 
- $\quad$ axiological, where culture is a set of values, arranged in a certain hierarchical sequence in accordance with the prevailing social trends (N.Z. Chavchavadze, G. Rickert, P. Sorokin, L.N. Stolovich) $[8 ; 9 ; 10$; $11]$;

- informational-semiotic, in which culture is a symbolic system, a set of cultural codes (Yu.M. Lotman, L. White) $[12 ; 13 ; 14]$;

- anthropological, within which culture is a selfvaluable system of artifacts, beliefs, and creeds of members of a certain community (R. Benedict, B. Malinovsky) $[15 ; 16]$;

- sociological, where culture is the arrangement of social life, expressed in the activities of its members and their development (A. Conte, M. Weber) [17].

"The School of the Dialogue of Cultures" (M.M. Bakhtin, V.S. Bibler,) [18] is significant for the understanding of the culture within the framework of our research. Here, culture is a peaceful and equal dialogue, in which cultures mutually enrich one another, while maintaining their unity. Such an understanding of culture is also reflected in the ideas on cultural relativism by $M$. Herskovits, on the dialogue of cultural worlds by G.S. Pomeranets [cited in 18], and on the polylogue of cultures by O.N. Astafyeva [cited in 18]. We will also mention an understanding of culture, indicated in the Intercultural Diary of the Council of Europe, and similar to the ideas of intercultural dialogue: culture is "something belonging to a specific national, ethnic or religious community", as well as "a dynamic process depending on the personal choice of its participants" [cited in 18, p.10].

Axiologization is a component of humanization of education, since in theory and in real practice it determines the composition and hierarchy of humanistic values of education, the system-forming element of which is the person as the main goal. It is obvious that axiologization is a process that combines the designated aspects of the development of educational activities of the institution and the personality of the student. And by educational institutions is a process that reveals the provision of quality education and personality the result of axiological is the development of the axiological attitude of students to knowledge, to the profession, to themselves and others in a stable meaningful professional and life value orientation.

According to N. Astashova, V. Kryzhko [19], a fruitful learning and teacher adoption of humanistic teaching values in education constitute major ideals, norms and guidelines that integrate human values and national priorities. However, in order for them to become national priorities, it is necessary to "live" and "experience", to defend and affirm the defined values in any socially useful, productive and creative activity in the vocational and educational. It is because the values that are mastered, and recognized in one's emotional sphere and individual activity may directly affect the professional formation and development of pedagogical skills of the future teacher educator. The principle of humanistic orientation of professional training involves a creation of personal developmental environment for public, social, moral and professional development of the future teacher-educator. This requires forming one's humanistic worldview based on universal values of humanity, including among others such concept as love, kindness, justice, freedom of thought and spirit [cited in 19].

Besides, Ye. Bondarevskaya, Z. Ravkin and V. Slastyonyn believe that the principle of humanistic orientation in its relation to man as the highest value in social life refers not only to an individual's creativity and development, but also to the functioning of the person as a citizen. Furthermore, it is signibicant that the professional development of an individual covers personal growth, manifested in one's intellectual and moral freedom, personal autonomy, professional selfimprovement and self-realization, self-creative identity, and spiritual potential. In addition, the humanistic orientation in vocational education of future teachers promotes the value orientation and guidance for any child, which is essential in the context of the investigated issue [cited in 19].

The University is a unique public place where two types of knowledge are formed: knowledge as a science and knowledge as a culture, that is, on the one hand, it contributes to the socio-cultural development of society, on the other-acts as a conductor of innovative technologies. The modern University becomes a guarantor, a mechanism for the realization of such a fundamental social need as stable, sustainable development of society [20].

In our opinion, the solution of the problem of improving the quality of training the future specialists for different fields of economics is impossible without addressing the valuemotivational components of the forthcoming professional activity.

The content of the concept of "value" is characterized by the majority of scientists through the allocation of characteristics inherent in one way or another forms of social consciousness: significance, normativity, utility, necessity, expediency. It is argued that the emergence of value is associated, on the one hand, with objects, phenomena, their properties, ways to meet certain needs of society, man. On the other hand, value acts as a judgment related to the assessment of an existing object, phenomenon by a person, society. It is emphasized that value is a form of manifestation of a certain kind of relationship between subject and object. Only when we consider the social existence of man in the aspect of the object-subject relationship, we can fix the phenomenon of value.

The pedagogical aspect of the problem of orientation of the person in the world, in general, is to make a wide range of objective values of culture the subject of awareness, experience as special needs of the person, to make objective values become subjectively significant, sustainable life orientations of the person, its value orientations. The significance of the study of value orientations of the individual is determined by the fact that they represent the main "channel of assimilation of the spiritual culture of society", the transformation of cultural values into incentives and motives of practical behavior of people. The formation of value orientations largely contributes to the process of personal development as a whole. 
Thus, the value of a person, the spiritual world of a person is determined by the degree of formation of his value orientation, the measure of his involvement in society, its history, the present, the range of his public interests, the richness and diversity of relations and relationships with society [cited in 15].

Modern educational standards, determined on the basis of the "State program of the Russian Federation" development of education "for 2013-2020" and built on the basis of the methodology of the competence approach, contain invariant values that should be formed in future professionals in the process of studying at the University. As our analysis shows, we can distinguish the following axiological competence, one way or another presented in the state regulations of higher professional education:

1) axiological competencies (possession of a culture of thinking, the ability to understand and analyze philosophical, socially and personally significant philosophical problems; understanding the value of culture, science, production, rational consumption; awareness of the social significance of one's future profession; high motivation to carry out professional activities);

2) cognitive competencies (the ability to cognitive activity; awareness of the need, need and ability to self-development, improve their skills and mastery; the ability to critically evaluate their strengths and weaknesses, to outline ways and choose means of developing strengths and eliminating shortcomings; awareness of the social significance of their future profession; the presence of high motivation to carry out professional activities; knowledge of one of the foreign languages at a level not lower than spoken);

3) social competencies (willingness to cooperate; communication skills, tolerance; willingness to cooperate with colleagues, to work in a team; the ability to find organizational and managerial decisions and the willingness to take responsibility for them);

4) organizational and managerial competencies (the ability to use organizational and managerial skills in professional and social activities).

Professional competence is a comprehensive personality profile and is considered by us as the ability to actualize the accumulated knowledge and skills and use them in the process of implementing their professional functions. It manifests itself and is acquired in activity and is an integral characteristic of a professional as a subject of activity; formed in the process of training; and also represents a systemic manifestation of knowledge, skills, experience that can successfully solve professional problems that make up the essence of professional activity.

In a broad sense, professional and axiological competence is a set of behavioral norms, values, ideas and concepts inherent in all members of the professional community that are determined by the specifics of professional activity [21].

\section{CONCLUSION}

We believe that the formed professional-axiological competence allows satisfying the interests of the future specialists in self-realization and self-development in professional activities not only by increasing knowledge, skills, authority, but also by forming values and norms of behavior in the professional sphere in which he will be work after graduation.

Their professional life and the quality of their professional work depend to a large extent on how professional and axiological competence is formed among future specialists. The development of professional and axiological competence of the student's personality implies qualitative changes in the value attitude to educational activities, to oneself (the formation of the image of I), to future professional activities (designing the image of future activities). This becomes a reality if the values mastered by students give cognition, cooperation, creativity and self-realization a value orientation.

The composition and hierarchy of professional values not only give direction to the future professional activities of the specialists from different fields of economics, but also determine its interaction with the world and people. Due to its value-orientating function, the educational process takes students into the sphere of philosophical understanding of social and educational reality.

\section{Acknowledgments}

This research was supported by Ural Federal University named after the first President of Russia, Boris Eltsyn, Ekaterinburg, Russia.

\section{References}

[1] A. Barrows, L. Conley, Internationalization of higher education: an institutional perspective, UNESCO, 2000, p. 5.

[2] N.D. Nikandrov, Goals of education at the turn of the XXI century, 1999. Retrieved from: http://www.eidos.ru/journal/1999/0215.htm.

[3] V.A. Karakovsky, Education for all. Moscow: Research Institute of school technologies, Library of the journal "Educational work in school", 2008.

[4] Federal Law "About Education" in the Russian Federation N 273-FL, dated December 29, 2012 with changes of 2019. Retrieved from http://zakon-ob-obrazovanii.ru/

[5] B.G. Ananyev, "To the Psychophysiology of Student Age", Modern Psychological and Pedagogical Problems of Higher Education, vol. 2, pp. 3-15, 1974.

[6] I.A. Zimnyaya, Pedagogical psychology, Moscow: Logos, 2000.

[7] F. Kröber, H. Klakhon, L.E. White, Culture as a Word and as a Scientific Concept. About Culture. Retrieved from https://studentslibrary.com/library/read/41726-kultura-kak-slovo-i-kak-naucnoeponatie-f-kreber-h-klakhon-i-le-uajt-o-kulture

[8] N.Z. Chavchavadze, Culture and Values, Tbilisi: Metsniereba, 170, 1984.

[9] G.Rickert, Nature Sciences and the Science of Culture, Moscow: Lawyer, 1995.

[10] P. Sorokin, Man. Society. Civilization, Moscow: Politizdat, 1992.

[11] L.N. Stolovich, "About universal values", Questions of philosophy, vol. 7, pp. 86-97, 2004.

[12] Yu.M. Lotman, To the Problem of the Typology of Culture. Works on sign systems, 1967. 
[13] L.A. White, The Science of Culture: A Study of Man and Civilization, N.Y., 1949.

[14] L.A. White, The Concept of Cultural Systems: A Key to Understanding Tribes and Nations, N.Y., 1975.

[15] R. Benedict, "Psychological Types in the Cultures of Southwest", Proceedings of the Twenty-third International Congress of Americanists, pp. 572-581, 1928.

[16] B. Malinowski, "The Functional Theory", A Scientific Theory of Culture and Other Essays, vol. 4, pp. 147-176, 1944.

[17] Classical sociology. $\quad$ Retrieved from http://www.grandars.ru/college/sociologiya/klassicheskayasociologiya.html

[18] Intercultural Communication Diary. European Context, Key Concepts and Theoretical Foundations. Retrieved from http://www.coe.int/t/dg4/autobiography/Source/AIE_ru/AIE_context_co ncepts_and_theories_ru.pdf

[19] R Prima, "Value orientations in professional training of teachereducators", Rozprawy Społeczne, vol. 4 (VIII), pp. 13-15, 2014.

[20] A.V. Artemkin, Development of Humanistic Value Orientations in Adolescents by Means of Folklore, Nizhny Novgorod, 25, 2015.
[21] B.M. Bim-Bad, Pedagogical Encyclopedic Dictionary, Moscow, pp. 192-193, 2002

[22] N. Davitishvili, "Cross-Cultural Awareness and Teaching English as a Second Language in the Context of Globalization", Sino-US English Teaching, vol. 14 (9), pp. 549-558, 2017.

[23] Yu.A. Romanov, T.A. Snegurova, "Intercultural communication and teaching Russian to international students at language summer courses. Integration of Education", vol. 21(3), pp. 371-384, 2017. Retrieved from https://cyberleninka.ru/article/n/ intercultural-communication-andteaching-Russian-to-international-students-at-language-summer-courses DOI: 10.15507/1991-9468.088.021.201703.371-384

[24] L.D. Stolyarenko, Fundamentals of Psychology, Rostov-on-Don: Phoenix, 1997.

[25] T. Thompson, N. Simmons, Family and Friends, Oxford University Press, 2015.

[26] K.A. Tunkina, Education of Tolerance of Adolescents in a Multicultural Environment of General Education Organizations, Kirov, 2015.

[27] E.M. Vereshchagin, V.G. Kostomarov, Language and Culture, Moscow, 1990. 